\title{
Clinical examination and X-ray: an old approach to a current problem
}

\author{
Patrícia Silva, ${ }^{1,2}$ Pedro Leão, ${ }^{1,2}$ André Goulart ${ }^{1,2}$
}

${ }^{1}$ Department of General Surgery, Hospital de Braga, Braga, Portugal

${ }^{2}$ Life and Health Sciences Research Institute (ICVS), Braga, Portugal

\section{Correspondence to Dr André Goulart, andre.b.goulart@gmail.com}

Accepted 1 December 2017

\section{DESCRIPTION}

Ingesting a foreign body is not an uncommon occurrence. Most pass through the gastrointestinal tract uneventfully, and perforation is rare. ${ }^{1}$ The preoperative diagnosis, in these cases, is always very difficult and the radiological examinations are not always able to resolve the diagnostic. The mortality and the morbidity remain still high first of all for the delay in the diagnosis and the advanced age of patients. ${ }^{2}$

A 50-year-old man without relevant medical history was admitted to the emergency department with 4 days evolution of abdominal pain. The patient presented continuous abdominal pain at the left lower quadrant. There was no nausea, vomiting, alterations of bowel habits or fever.

On examination, the patient was in painful distress. Vital signs revealed tachycardia at $110 \mathrm{bpm}$, blood pressure of $120 / 64 \mathrm{~mm} \mathrm{Hg}$ but no fever $\left(36.8^{\circ} \mathrm{C}\right)$. Abdominal examination revealed diffuse tenderness and pain more intense at the left lower abdomen, peritoneal signs, tympany and reduced bowel sounds. Laboratory tests showed an elevated white cell count (15 000/ $\mathrm{L}$ with left shift). An abdominal X-ray revealed free intraperitoneal air and an image compatible with a foreign body at left lower abdomen (figure 1).

The decision was made to perform an exploratory laparotomy. Purulent peritonitis was observed and bowel inspection revealed a perforation of colon sigmoid by a toothpick (figure 2). The foreign body was removed, and the sigmoid perforation was repaired with interrupted sutures PDS $3-0$. The postoperative course was uneventful with discharge at fifth postoperative day.

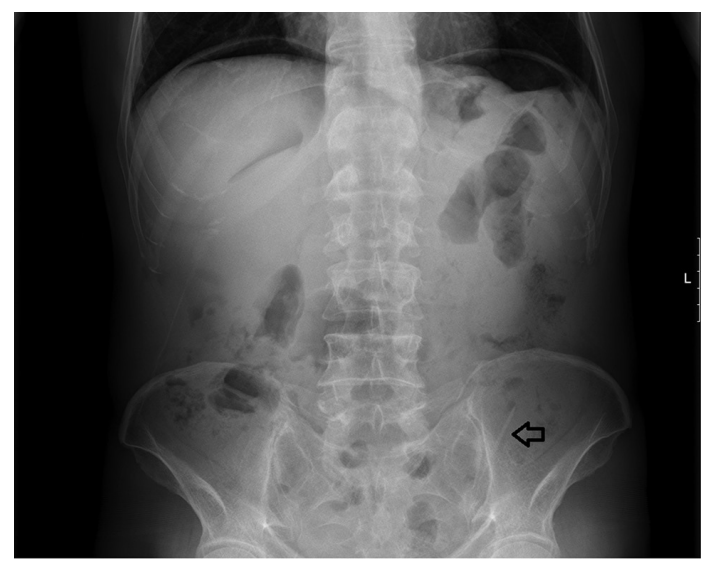

Figure 1 Abdominal X-ray (arrow: foreign body).

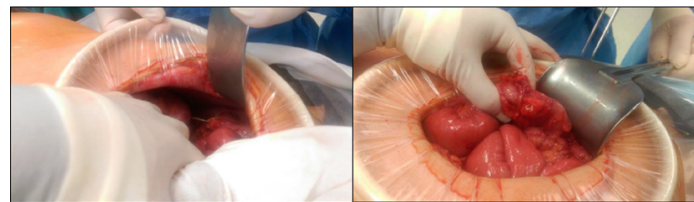

Figure 2 Sigmoid perforation.

Acute abdominal pain accounts for 5\%-10\% of all emergency department visits. Rapid and accurate diagnosis is critical to ensure optimal outcomes. ${ }^{3}$ Despite the increased availability of CT scans in the emergency departments, an abdominal X-ray continues to be an important imaging method to approach an acute abdomen. The advantages of X-ray in this setting are that it is easier to use, cheaper and quicker than a CT and provides, like in this case, sufficient results to make a decision.

Like we learn, there is a 'step' in imagiological studies that we cannot overcome. So, the main idea of this work is to call attention to young doctors that there is a place for 'old' exams in modern medicine.

\section{Learning points}

- Abdominal pain is a common admission reason to the emergency department.

- X-ray allows a rapid evaluation of the patients with acute abdominal pain and, in some cases, is sufficient to make a decision.

Contributors PS: data collection, drafting the article, final approval of the version to be published. PL: data analysis and interpretation, critical revision of the article, final approval of the version to be published. AG: conception or design of the work, drafting the article, critical revision of the article, final approval of the version to be published.

Competing interests None declared.

Patient consent Obtained.

Provenance and peer review Not commissioned; externally peer reviewed.

(C) BMJ Publishing Group Ltd (unless otherwise stated in the text of the article) 2017. All rights reserved. No commercial use is permitted unless otherwise expressly granted.

\section{REFERENCES}

1 Rodríguez-Hermosa JI, Codina-Cazador A, Sirvent JM, et al. Surgically treated perforations of the gastrointestinal tract caused by ingested foreign bodies. Colorectal Dis 2008;10:701-7.

2 Versaci A, Saladino E, Rossitto M, et al. [Intestinal perforation by ingested foreign bodies in the digestive tract: an insidious pathology always of interest. Our experience]. G Chir 2010;31:379-82.

3 de Burlet $\mathrm{K}$, Lam A, Larsen P, et al. Acute abdominal pain-changes in the way we assess it over a decade. N Z Med J 2017;130:39-44. 
Copyright 2017 BMJ Publishing Group. All rights reserved. For permission to reuse any of this content visit http://group.bmj.com/group/rights-licensing/permissions.

BMJ Case Report Fellows may re-use this article for personal use and teaching without any further permission.

Become a Fellow of BMJ Case Reports today and you can:

- Submit as many cases as you like

- Enjoy fast sympathetic peer review and rapid publication of accepted articles

Access all the published articles

- Re-use any of the published material for personal use and teaching without further permission

For information on Institutional Fellowships contact consortiasales@bmjgroup.com

Visit casereports.bmj.com for more articles like this and to become a Fellow 